\title{
Occurrence and Spread after 18 Years of Invasion by Fallopia $\times$ bohemica (Slovakia)
}

\author{
Žaneta Pauková' \\ 1 Department of Ecology, Slovak University of Agriculture, Mariánska 10, 94976 Nitra, Slovakia \\ e-mail: zaneta.paukova@uniag.sk
}

\begin{abstract}
At the global level, the invasion of alien organisms is considered the second largest threat to biodiversity. Hybrid Japanese Knotweed (Fallopia $\times$ bohemica) is an invasive alien species in Slovakia, which is indigenous to eastern Asia. Ragweed is a significant threat to agriculture in Central Europe. In this study, we compare the current occurrence and spread of invasive populations of hybrid Fallopia $\times$ bohemica (Polygonaceae) in Hlohovec town (SW Slovakia) in intensively farmed agricultural landscape after eighteen years. In 2001, it had colonized the area of $1520 \mathrm{~m}^{2}$ on 54 localities and in 2011 it increased by $120 \%\left(3338 \mathrm{~m}^{2}, 63\right.$ localities $)$; however, in 2018 it decreased by $9 \%$ (3051 $\mathrm{m}^{2}, 43$ localities). Surprisingly, the research results in the period 2011-2018 showed that the further spread of hybrid in Hlohovec was not confirmed; even the total colonized area had decreased. The main reason for the reduction of surface area occupied by F. x bohemica is the management measures carried out on habitats railway communications, roads and extensively cultivated fields (home gardens). The size of the areas in 2018 was significantly dependent on the size of the areas in $2001(\mathrm{r}=0.682)$ and in $2011(\mathrm{r}=0.907)$.
\end{abstract}

Keywords: agricultural landscape, invasive plant, mapping, Fallopia, management.

\section{INTRODUCTION}

Invasive plants are defined as non-native species that spontaneously spread and displace native species from their natural biotopes and reduce the biodiversity [Act No. 543/2002 on Nature and Landscape Protection]. The valid list of invasive plant species in Slovakia is presented in the regulation No. 24/2003 and No. 158/2014. In Slovakia, three taxa of the Fallopia genus belong to the invasive plant species, which have to be eliminated, according to the law. Successfully spreading species in Slovakia include F. japonica (Japanese knotweed), F. sachalinensis (Giant knotweed) and their hybrid $F . \times$ bohemica .

This paper presents the results of spread of invasive plant populations Fallopia $\times$ bohemica in the urban area of Hlohovec town (SW Slovakia) after eighteen years, evaluation of the selected population-biological characteristics and performance of the plant management. The release of invasive plant species from urban area into undeveloped area is possible. It can threaten biodiversity and cause farmers and policy holders to bear the cost of its removing. With this study, we want to help to reconstruct the expansion of selected invasive neophyte on a local level, because there is a lack of detailed studies based on plants-mapping in the chosen location.

\section{MATERIAL AND METHODS}

The F. japonica (Houtt.) Ronse Decraene [syn.: Polygonum cuspidatum Sieb. et Zucc] and F. sachalinensis (F. Schmidt) Ronse Decraene [syn.: Polygonum sachalinense F. Schmidt, Reynoutria sachalinensis (F. Schmidt) Nakai] species were introduced to Europe from eastern Asia as an ornamental plant in the middle of the $19^{\text {th }}$ century and very quickly began to invade [Bailey and Wisskirchen 2006]. Parental species, as well as their hybrid $F . \times$ bohemica [(Chrtek et Chrtková) J.P. Bailey] belong to the plants with clonal growth [Bailey and Wisskirchen 2006, 
Barney et al. 2006]. Fallopia $\times$ bohemica is considered as the most troublesome species of the Fallopia genus [Sołtysiak and Brej 2012].The first data about the occurrence of $F$. japonica in Slovakia came from the 1920s and 1930s [Eliáš 2004, Eliáš 2008]. F. japonica is a perennial, dioecious plant. The stems are $1.5 \mathrm{~m}$ to $3.5 \mathrm{~m}$ high, straight, branched at the top, often arcuate, hollow. The base of lower leaves is truncate, apex acuminate, and undersides entirely glabrous. They form an extensive root system, richly branched, reaching up to a width of $15 \mathrm{~m}$ to $20 \mathrm{~m}$ from the parent plant and a depth of $2 \mathrm{~m}$ to $3 \mathrm{~m}$ [Bailey and Wisskirchen 2006, Barney et al. 2006, Vinogradova et al. 2010, Rendeková et al. 2018]. It was found for the first time in 1982 near town Náchod in the Czech Republic and described as Reynoutria $\times$ bohemica [Chrtek and Chrtková 1983]. All plants have got morphologically androgynous flowers, but functionally unisexual flowers predominate. The fruit is black to black-brown coloured triangular achene. The base of lower leaves is weakly to moderately cordate at base, apex acuminate, and undersides of larger leaver with numerous short stout hairs. The leaves of the hybrid are intermediate in size: between the 15 to $40 \times 7$ to $25 \mathrm{~cm}$ leaves of $F$. sachalinensis and the $15 \times 8-10 \mathrm{~cm}$ leaves of $F$. japonica [Haines 2011, Invasive Species Compendium 2018].

Hlohovec is located in south-western Slovakia in the Trnava Self-Governing Region. It stretches in a dell between the southern part of mountain range Považský Inovec and a part of the Nitra hill range. River Váh and its alluvium separate it from the Trnava hills. The area of the cadastre is $6412 \mathrm{ha}$. The urban area is $7375677 \mathrm{~m}^{2}$, while the number of inhabitants is 22396 . The altitude of the town square is $156 \mathrm{~m}$. Hlohovec belongs to the hot and dry climate zone, with mild winters. A common soil type is brown Luvisol, locally Luvisol from loess and near the river Fluvisol [Š́ly and Šurina 2002]. Richards et al. [2008] reported Knotweed taxa from saline habitats of The United States. Additionally, they can tolerate sulphurous soils.

The crux of this work is the field research performed during the period May-September 2018, using the mapping method. We recorded taxon, location and type of biotope according to Ružičková et al. [1996]. We measured the size of vegetation area $\left(\mathrm{m}^{2}\right)$ and the height of the highest stems (m). Every shoot with leaves or with side branches and inflorescence was considered as an individual (ramet, i-individual). We found out the average density of individuals (low $1-15$ i.m ${ }^{-2}$, medium 16-30 i.m ${ }^{-2}$, high 31 and more i.m ${ }^{-2}$ ) with the method of counting individuals, always on a $1 \times 1 \mathrm{~m}$ square inside the population in order to avoid the edge effect. The evaluation of ramet density was realized in June, when the number of individuals is highest. We determined the percentage of areas with non-regulated populations, in which the plants have been not removed and regulated ones, where the management measures were performed regularly. The nomenclature of species in communities is referred according to Marhold and Hindák [1998].

\section{RESULTS AND DISCUSSION}

The first record of the collection of F. japonica in the form of herbarium sheet in Hlohovec comes from 1966 from the park on the Dilongova street [Ješko and Vavro 1966, Feráková and Ješko 1969]. The occurrence of F. japonica and F. sachalinensis was not recorded in 2018. During the eighteenth year of research, it 43 localities of hybrid F. $\times$ bohemica in Hlohovec on the area of approximately $3051 \mathrm{~m}^{2}$ have been registered. At the recent spreading, the area colonized by the hybrid in 2018 decreased by $9 \%$ in comparison to year 2011 (3338 $\mathrm{m}^{2}, 63$ localities). In 2018, has already spread on occupied sites, especially along dykes of the river Váh ( $48 \%$ of the total area occupied by hybrid) and along the railways (27\%), less frequently used road (15\%) and extensively cultivated fields (10\%) (Fig. 1).

Although there is little data on the $F$. $\times$ bohemica hybrid, it is likely that they are much more frequent than it is reported in Slovakia. The lack of data must be taken into account in the interpretation of the abundance and distribution of these hybrids [Medvecká et al. 2012]. Hybrid $F$. $\times$ bohemica was spread not only in Slovakia [Eliáš 2004, Pauková 2013, Beniak et al. 2015, Fehér et al. 2016], but also in many other countries such as Czech Republic [Chrtek and Chrtková 1983], in Poland [Sołtysiak and Brej 2012, Sołtysiak and Brej 2014], Belgium [Tiébré et al. 2008], Austria, Germany, Netherlands, Ireland, Norway [Bailey and Wisskirchen 2006, Follak et al. 2018], USA [Lavoide 2017, Strassel and Connolly 2018] and other.

The comparison of the obtained data on the surface representation of $F \times$ bohemica along dykes showed that during the first year of research, 


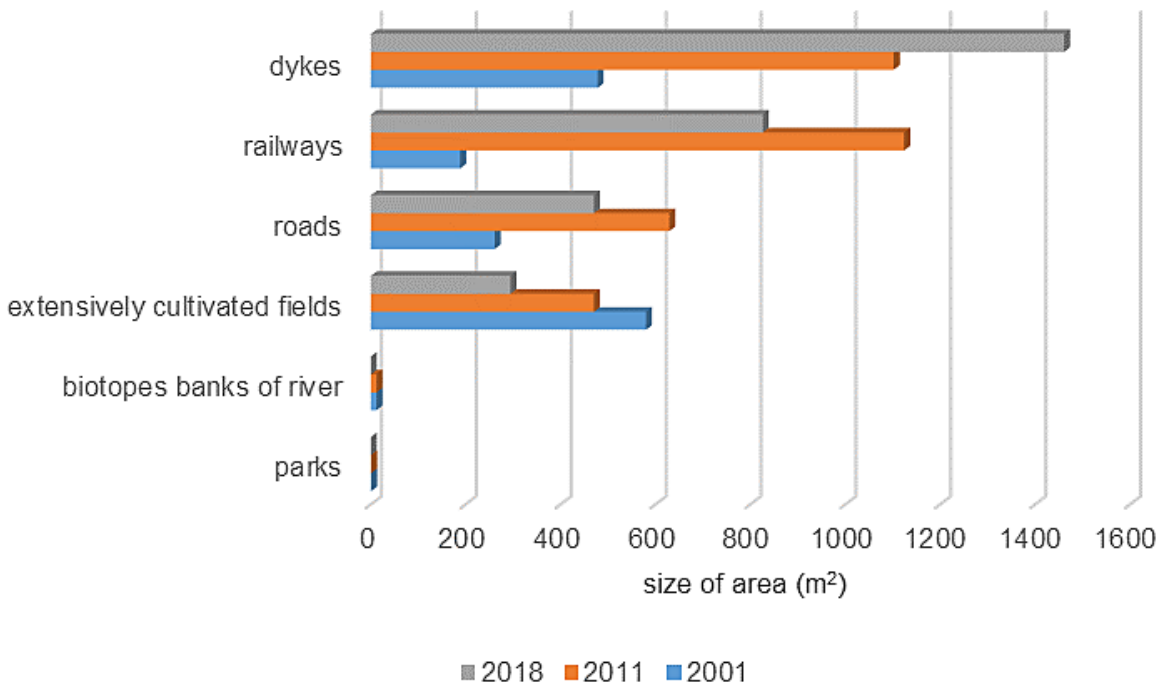

Figure 1. Area representation of Fallopia $\times$ bohemica according to biotope types

the observed plants colonized an area of $478 \mathrm{~m}^{2}$ Váh [Pauková 2013] and eighteen years later, the area was three times larger $\left(1461 \mathrm{~m}^{2}\right)$. The area of localities spreading along the roads and railways decreased by up to $25 \%$ and $27 \%$ for the last eight years. It was found a significant decrease of the area extensively cultivated fields (home gardens) by $49 \%$ (Fig. 1 ).

In the last years, mainly the invasive species Helianthus tuberosus has spread along the river Váh [Pauková 2013], which we can also confirm with our research in 2018. One population of $F$. $\times$ bohemica on the banks of the river Váh on the left side was removed. The significance of water flows is variable for different types of invasive plants found other authors [Beniak et al. 2015, Fehér et al. 2016]. It is less significant for the species of the Fallopia genus, which corresponds well with our results. In the Moscow area, the species occur mainly on river banks, in the European part of Russia on ruderal sites [Vinogradova et al. 2010]. The presence of knotweeds was confirmed in over $23.0 \%$ of urban areas of the one of the Polish cities [Soltysiak and Brej 2014]. In Belgium, F. $\times$ bohemica spreads in cities $(70 \%)$, along roads and rivers. The overgrowth area increased within a year by more than $30 \%$ [Tiébré et al. 2008].

The field survey shows that the greatest danger comes from of the largest populations of $F$. $\times$ bohemica (Table 1).

Figure 2 shows that the number of populations (especially over $120 \mathrm{~m}^{2}$ ) decreased within the observed years 2011-2018, which indicates a successful management measures of $F$. $\times$ bohemica.

In 2011, the hybrid formed mainly monocenoses ( $75 \%$ of localities), but ten years later, was their proportion only one-third (35\%) [Pauková 2013]. In 2018, F. x bohemica formed mainly polycenoses $(70 \%)$. We think this is because of

Table 1. Population-biological characteristics of the largest populations of Fallopia $\times$ bohemica in town Hlohovec (Slovakia)

\begin{tabular}{|c|c|c|c|c|c|c|c|c|c|}
\hline \multirow{2}{*}{ Type of biotope } & \multicolumn{3}{|c|}{ area $\left(m^{2}\right)$} & \multicolumn{3}{|c|}{ population density $\left(\mathrm{i} \cdot \mathrm{m}^{-2}\right)$} & \multicolumn{3}{|c|}{ height of shoots $(\mathrm{m})$} \\
\hline & 2001 & 2011 & 2018 & 2001 & 2011 & 2018 & 2001 & 2011 & 2018 \\
\hline \multicolumn{10}{|l|}{ A610000 Dykes } \\
\hline River Váh & 60 & 161 & 169 & high & high & medium & 3.5 & 3.8 & 3.9 \\
\hline River Váh & 80 & 180 & 180 & high & medium & high & 3.7 & 3.7 & 4.0 \\
\hline River Váh & 51 & 147 & 130 & high & high & high & 3.5 & 3.5 & 3.7 \\
\hline River Váh & 139 & 312 & 360 & high & medium & medium & 3.6 & 3.8 & 4.2 \\
\hline \multicolumn{10}{|l|}{ A510000 Railways } \\
\hline Železnična street & 27 & 307 & 115 & medium & high & high & 3.0 & 3.6 & 3.5 \\
\hline Železnična street & 42 & 505 & 462 & medium & high & medium & 3.2 & 3.7 & 3.9 \\
\hline \multicolumn{10}{|l|}{ A520000 Roads } \\
\hline Mierova street & - & 169 & 115 & - & high & high & 3.8 & 3.9 & 3.9 \\
\hline
\end{tabular}




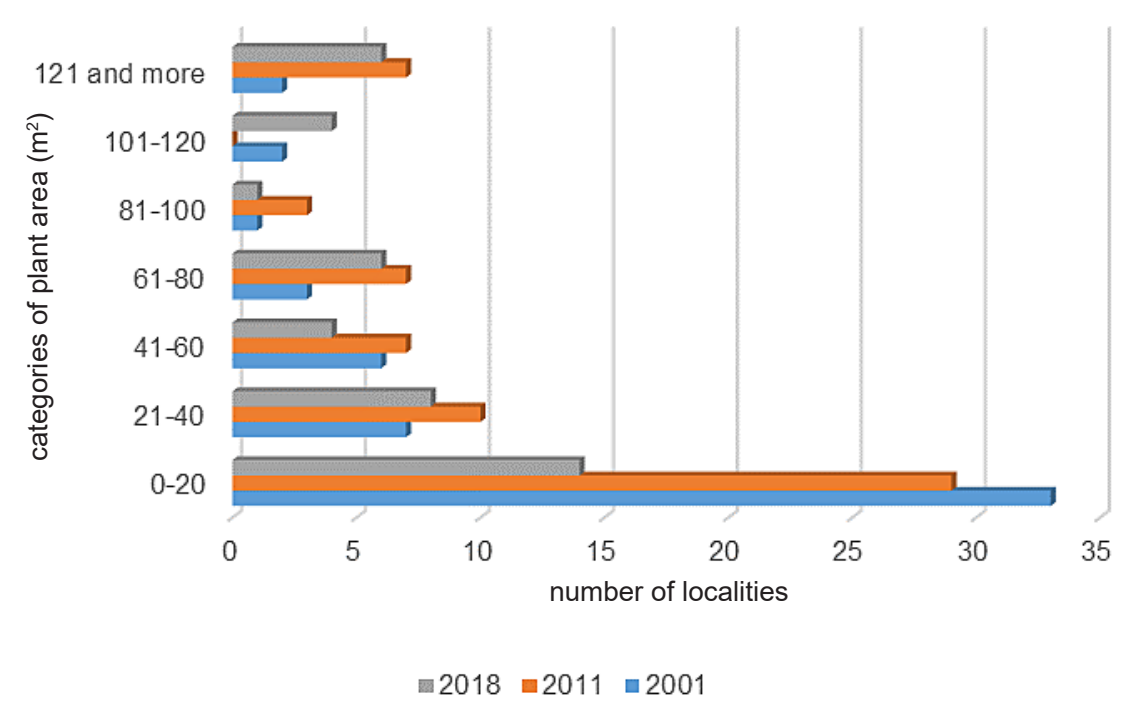

Figure 2. Frequency of Fallopia $\times$ bohemica localities depending on the size of the overgrowth area

an increase in the vegetation surface and gradual displacing of other species of the undergrowth (sub-canopy), but also through the periodical regulation on the extensively cultivated fields, which created approximately $52 \%$ of the total localities occupied by $F$. $\times$ bohemica . In other phytocenoses, the most frequently occurring species were Ailanthus altissima Mill. (Swingle), Elytrigia repens L. Desv., Urtica dioica L., Convolvulus arvensis L., Capsella bursa pastoris (L.) Medik. and others.

The obtained results concerning the size of F. $\times$ bohemica areas show that their size in 2018 was highly significantly dependent on the size of the areas in $2011(\mathrm{r}=0.907, \mathrm{P}<0.01)$ (Fig. 3) and $2001(\mathrm{r}=0.682, \mathrm{P}<0.01)$ (Fig. 4) and the trend has a power character. This means that the size of the overgrowth areas in 2001 and 2011 had a statistically significant effect on the size of the areas in 2018 at the selected level of significance.

\section{Regulated and unregulated populations}

The removal of $F . \times$ bohemica plants in Hlohovec was carried out on $72 \%$ of the total number of localities, in the so-called regulated populations. However, in terms of area, $1590 \mathrm{~m}^{2}$ represents $52 \%$ of the total area colonized by the hybrid. In July 2018, the average height of the plants in regulated populations ranged from 0.2 to 0.8 meter. The plants were regularly cut three times during the growing season. The number of unregulated populations along the dykes in Hlohovec represented $28 \%$ of the total populations colonized by the hybrid. The average height of plants in summer 2018 ranged from 3.5 to 4.2 meters. The population density of ramets was characterized by a medium density (16-30 i.m $\mathrm{m}^{-2}$. We conclude that the area of unregulated populations (Fig. 5) occupied decreased from 80 to $48 \%$ $\left(1461 \mathrm{~m}^{2}\right)$ of the total area occupied by the hybrid. Regular monthly cutting of plants reduces the spread of the vegetation, but does not eliminate it [Barney et al. 2006].

\section{CONCLUSIONS}

F. $\times$ bohemica is a successfully spreading invasive hybrid in the Hlohovec town in Slovakia. In 2018, it had colonized the area $\left(3051 \mathrm{~m}^{2}\right)$, and decreased by $9 \%$ in relation to $2011\left(3338 \mathrm{~m}^{2}\right)$. The size of the areas in 2018 was highly significantly dependent on the size of the areas in 2001 $(r=0.682)$ and $2011(r=0.907)$. The hybrid has spread mainly along the dykes of the river Váh ( $48 \%$ of the total area occupied by the hybrid) and railways $(27 \%)$, less frequently used roads (15\%) and extensively cultivated fields (10\%). The area of regulated populations increased from $20 \%$ to $52 \%$ of the total area occupied by the hybrid, but it is still necessary to carry out management measures.

\section{Acknowledgements}

This work was supported by the Slovak Grant Agency for Sciences (VEGA). Grant No. $1 / 0767 / 17$. 


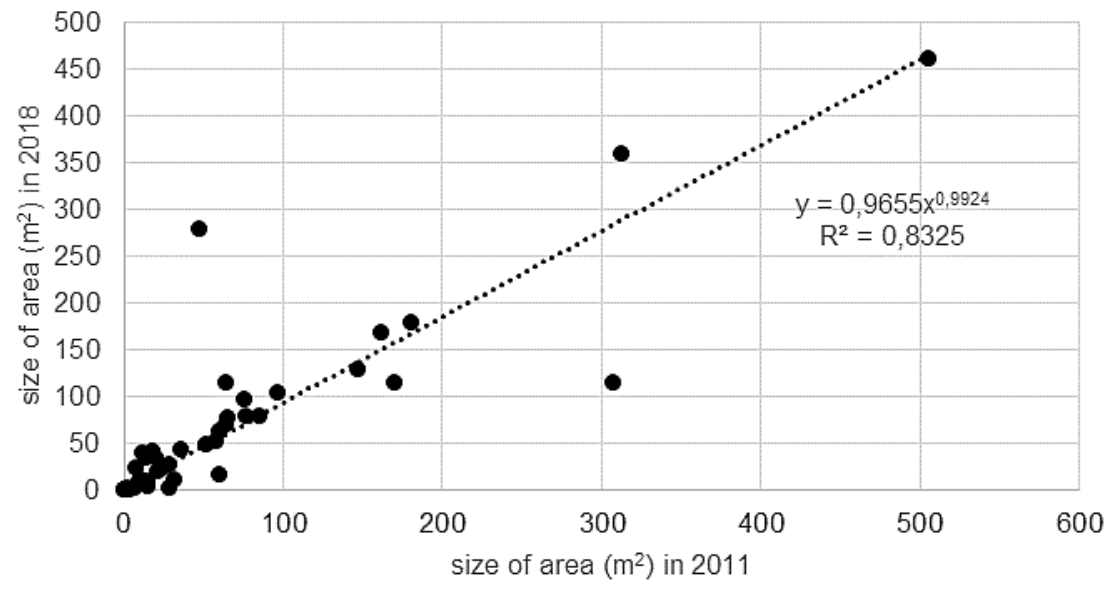

Figure 3. Power dependence of the Fallopia $\times$ bohemica areas

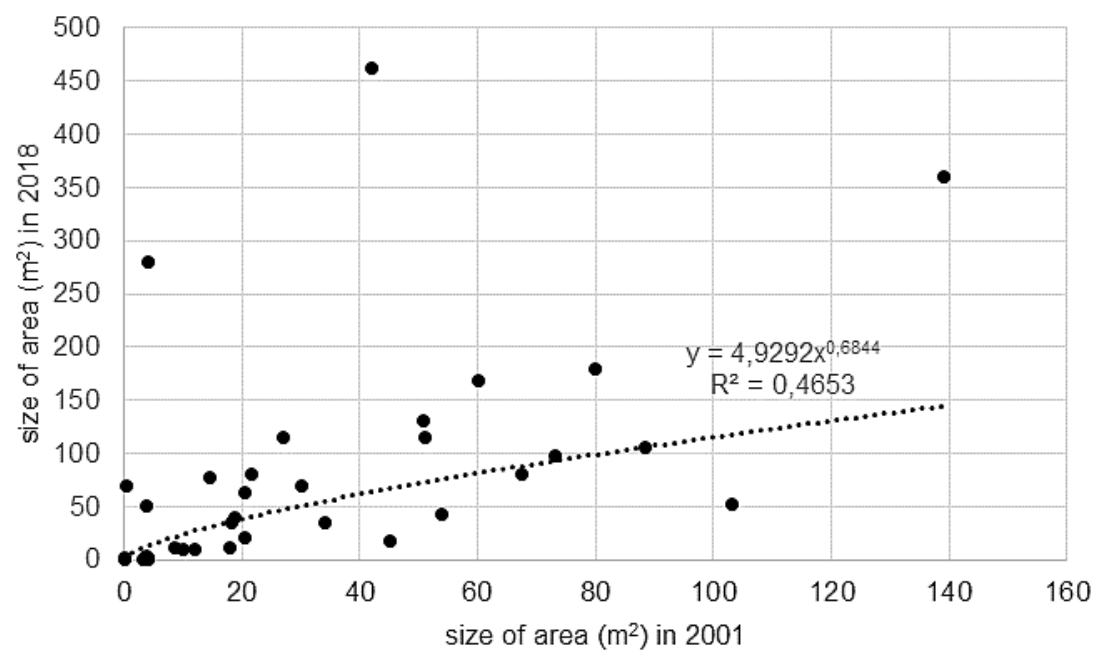

Figure 4. Power dependence of the Fallopia $\times$ bohemica areas

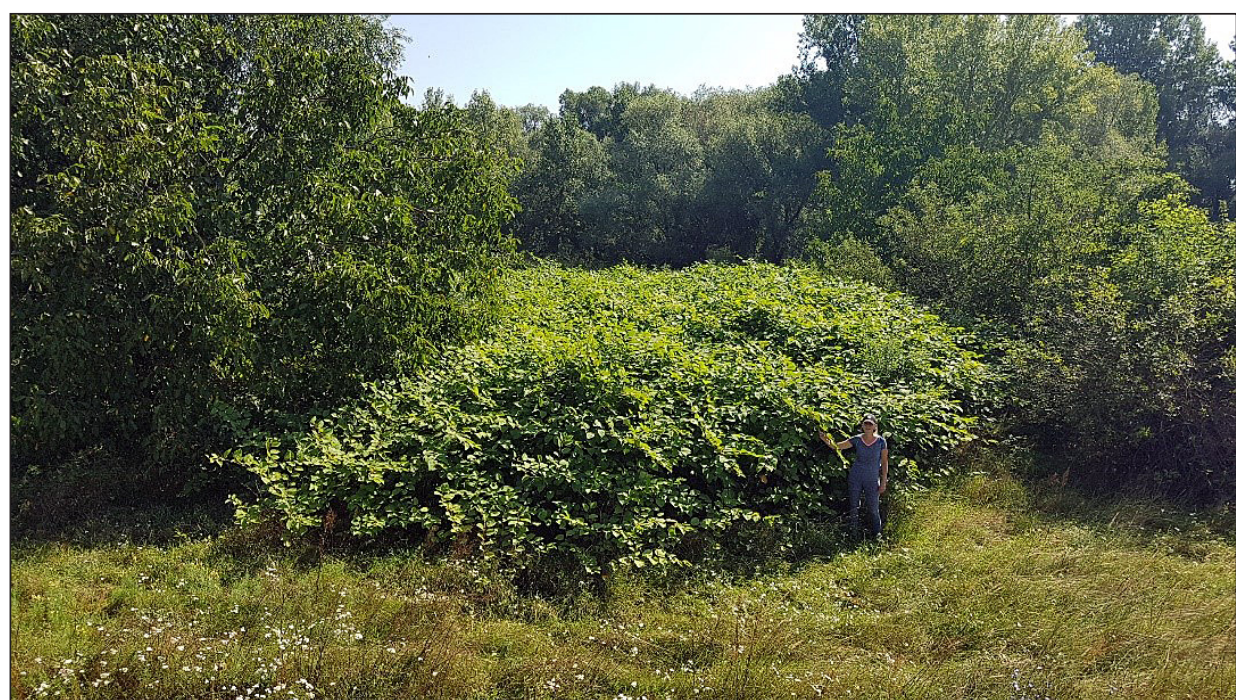

Figure 5. Unregulated population of the Fallopia $\times$ bohemica in town Hlohovec 


\section{REFERENCES}

1. Act No. 543/2002 on Nature and Landscape Protection, Notices No. 24/2003 and No. 158/2014 (in Slovak).

2. Bailey J.P., Wisskirchen R. 2006. The distribution and origins of Fallopia $\times$ bohemica (Polygonaceae) in Europe. Nordic Journal of Botany, 24(2), 173-199.

3. Barney J.N., Tharayil N., DiTommaso A., Bhowmik, P.C. 2006. The biology of invasive alien plants in Canada. 5. Polygonum cuspidatium Sieb. \& Zucc. [= Fallopia japonica (Houtt.) Ronse Decr.] Can. J. Plant Sci., 86, 887-905.

4. Beniak M., Pauková Ž., Fehér A. 2015. Altitudinal occurrence of non-native plant species (neophytes) and their habitat affinity to anthropogenic biotopes in conditions of south-western Slovakia. Ekológia, 34(2), 163-175.

5. Eliáš P. 2004. Fallopia $\times$ bohemica - invasive plant of hybrid origin, new for the list of flowering plants of Slovakia. Acta horticulturae et regiotecturae, 7(1), 4-9 (in Slovak).

6. Eliáš P. 2008. First reports of Reynoutria $\times$ bohemica occurrence in Slovakia. Bull. Slov. Bot. Spoločn., 30(2), 195-205 (in Slovak).

7. Fehér A., Halmová D., Fehér Pindešová I., Zajác P., Čapla J. 2016. Distribution of invasive plants in the Nitra river basin: threats and benefits for food production. Potravinárstvo, 10(1), 605-611.

8. Feráková V., Ješko T. 1969. Herbarium specimens in museum in town Hlohovec. Pleuropterus cuspidatus (Sieb et Zucc) H. gross. (in Slovak).

9. Follak S., Eberius M., Essl F., Fürdös A., Sedlacek N., Trognitz F. 2018. Invasive alien plants along roadsides in Europe. Bulletin OEPP/EPPO Bulletin, 48(2), 256-265.

10. Haines A. 2011. Flora Novae Angliae: A Manual for the Identification of Native and Naturalized Higher Vascular Plants of New England. Yale University Press, New Haven, CT.

11. Chrtek J., Chrtková A. 1983. Reynoutria $\times$ bohemica new hybrid from Polygonaceae. Čas. Nár. Muz., Praha, ser. Nat., 152(2), 120 (in Czech).

12. Invasive species compendium. 2018. Website (http://www.cabi.org). Accessed October 2018.

13. Ješko T., Vavro R. 1966. Herbarium specimens in museum in town Hlohovec. Pleuropterus cuspi- datus (Sieb et Zucc) H. gross. Inventory number 140-52/66 (in Slovak).

14. Lavoide C. 2017. The impact of invasive knotweed species (Reynoutria spp.) on the environment: review and research perspectives. Biological Invasions, 19(8), 2319-2337.

15. Marhold K., Hindák F. 1998. List of higher and lower plants of Slovakia. Veda, Bratislava (in Slovak).

16. Medvecká J., Kliment J., Májeková J., Halada L., Zaliberová M., Gojdičová E., Feráková V., Jarolímek I. 2012. Inventory of the alien flora of Slovakia. Preslia, 84, 257-309.

17. Pauková Ž. 2013. The current spread of invasive neophytes of genus Fallopia in town Hlohovec (SW Slovakia) after ten years. Journal of Central European Agriculture, 14(1), 124-133.

18. Rendeková A., Mičieta K., Randáková Z., Miškovic J. 2018. Dynamics of the species diversity and composition of the ruderal vegetation of Slovak and Czech cities. Hacquetia, 17(2), 171-188.

19. Ružičková H., Halada L', Jedlička L., Kalivodová. E. 1996. Biotopes of Slovakia. ÚKE SAV, Bratislava (in Slovak).

20. Richards C.H.L., Walls R.L., Bailey J.P., Parameswaran R., George T., Pigliucci M. 2008. Plasticity in salt tolerance traits allows for invasion of novel habitat by Japanese Knotweed s.l. (Fallopia japonica and F. $\times$ bohemica, Polygonaceae). American Journal of Botany, 95, 931-942.

21. Sołtysiak J., Brej T. 2012. Characteristics that make the Fallopia genus (Polygonaceae) highly invasive. Ecological Question, 16, 23-27.

22. Sołtysiak J., Brej T. 2014. Invasion of Fallopia Genus Plants in Urban Environment. Pol. J. Environ. Stud., 23(2), 449-458.

23. Strassel L.H., Connolly B.A. 2018. Occurence of knotweed hybrid, Fallopia x bohemica (Polygonaceae) in New Hampshire. Rhodora, 120(981), 87-88.

24. Šály R., Šurina B. 2002. Soil maps. Atlas of landscape of Slovakia. MŽP SR, Bratislava, 106-107 (in Slovak).

25. Tiébré M.S., Saad L., Mahy G. 2008. Landscape dynamics and biotope selection by the alien invasive Fallopia (Polygonaceae) in Belgium. Biodiversity Conservation, 117.

26. Vinogradova JU.K., Majorov S.R., Chorun L.V. 2010. Black book of flora of Central Russia. GEOS, Moskva (in Russian). 